Edyta Pijet-Migoń

https://orcid.org/0000-0002-3048-8903

Wyższa Szkoła Bankowa we Wrocławiu Instytut Turystyki

edyta.migon@wsb.wroclaw.pl

\title{
ROZWÓJ PASAŻERSKIEGO TRANSPORTU LOTNICZEGO W POLSCE W LATACH 1989-2019 - JEGO SKUTKI DLA PORTÓW LOTNICZYCH I IMPLIKACJE DLA MIAST
}

\begin{abstract}
Abstrakt: Artykuł przedstawia zarys najważniejszych zmian, które zaszły w polskich dużych miastach wskutek rozwoju transportu lotniczego po przemianach ustrojowych. Zmiany te miały charakter zarówno przestrzenny - dotyczyły m.in. rozbudowy infrastruktury lotniskowej i okołolotniskowej oraz układu transportowego, jak i funkcjonalny. Wzrost dostępności transportowej był istotnym czynnikiem wyboru lokalizacji firm i dużych wydarzeń, a także wpłynął na rozwój turystyki, powodując dalsze konsekwencje w postaci rozwoju infrastruktury hotelowej i nowych form zakwaterowania.

Słowa kluczowe: transport lotniczy, porty lotnicze, miasta, infrastruktura, turystyka.
\end{abstract}

\section{GROWTH OF AIR TRANSPORT SERVICES IN POLAND IN 1989-2019: THE CONSEQUENCES FOR AIRPORTS AND IMPLICATIONS FOR AIRPORT-HOSTING CITIES}

\begin{abstract}
The article outlines the most important changes due to the development of air transport that have occurred in large Polish cities in the period following the change of political-economic system in 1989. These changes have had both spatial and functional dimensions. The former includes expansion of airport and airport-related infrastructure and alterations to the ground transport network. The increasing accessibility of air transport has proved important for decision-making in respect to the location of new commercial activities and large events, as well as contributing to the growth of incoming tourism. In turn this has caused an expansion of hotel networks and the emergence of new forms of accommodation.
\end{abstract}

Keywords: air transport, airports, cities, infrastructure, tourism.

\section{WPROWADZENIE}

Transport lotniczy w Polsce jest współcześnie częścią rynku europejskiego i światowego, dlatego na jego funkcjonowanie wpływ ma wiele czynników zarówno o zasięgu globalnym, jak i krajowym. Czynniki te mają charakter polityczny, gospodarczy, technologiczny, ale również prawny i organizacyjny (Hawlena, 2012a; Rucińska, Ruciński, Tłoczyński, 2012). Pomiędzy rozwojem transportu a rozwojem gospodarczym miast i regionów zachodzi efekt synergii (Huderek-Glapska, 2011; Marciszewska, Kaliński, 2009; Olipra, 2016; Rucińska, Ruciński, 2017). Zwiększenie oferty połączeń lotniczych może przyczyniać się do rozwoju miast i regionów, ale równocześnie wielkość ruchu lotniczego i dostępność lotnicza wskazują na rolę miast i regionu w strukturze powiązań gospodarczych i społecznych.

Od początku przemian polityczno-gospodarczych w Polsce mija 30 lat, jest to okazja do podsumowań zmian, które zaszły w tym czasie, a dotyczyły wielu aspektów gospodarki, w tym sektora transportu lotniczego. Warto zwrócić uwagę na znaczący wzrost liczby pasażerów linii lotniczych w omawianym okresie. Tuż po rozpoczęciu przemian ustrojowych transport lotniczy był bardzo mało popularnym, elitarnym środkiem komunikacji, natomiast $\mathrm{w}$ drugiej dekadzie XXI w. stał się powszechnie dostępny. W $1990 \mathrm{r}$. we wszystkich polskich portach lotniczych obsłużono niecałe $3 \mathrm{mln}$ pasażerów, w 2019 r. liczba pasażerów wyniosła prawie $49 \mathrm{mln}$. Na początku lat 90 . XX w. międzynarodowy ruch pasażerski odbywał się prawie wyłącznie $\mathrm{z}$ lotniska Warszawa Okęcie, w 2019 r. działało 12 portów regionalnych, z których tylko port lotniczy w Zielonej Górze nie obsługiwał międzynarodowego ruchu rozkładowego.

Celem artykułu, który ma charakter przeglądowy i podsumowujący, jest przedstawienie najważniejszych 
przemian rynku pasażerskiego transportu lotniczego w Polsce w ostatnich trzech dekadach, wskazanie na przyczyny zmian oraz próba odpowiedzi na pytanie, czy i w jakim zakresie zwiększenie dostępności usług transportu lotniczego wpłynęło na funkcjonowanie miast, w których zlokalizowane są porty lotnicze. Jest oczywiste, że przemiany funkcjonalne i społeczne zachodzące w miastach mają bardzo złożony i kompleksowy charakter, stąd często trudno jest jednoznacznie określić ich przyczynę, ponieważ wpływa na nie wiele czynników, dodatkowo wzajemnie ze sobą powiązanych. Jednym z nich jest jednak niewątpliwie rozwój transportu lotniczego i wzrost jego dostępności - rozumianej bardzo szeroko jako oferta sieci połączeń oraz dostępność cenowa i czasowa. Wpływ rozwoju komunikacji lotniczej może być bezpośredni lub pośredni, widoczny zarówno w rozbudowie infrastruktury obsługującej porty lotnicze, jak i, trudniejszych do wykazania, powiązaniach przyczynowo-skutkowych w sferze gospodarczej i społecznej. Uzasadnione jest zatem postawienie hipotezy, że wpływ ten będzie największy w miastach mających porty lotnicze obsługujące dużą liczbę pasażerów.

Jako materiały źródłowe w pracy wykorzystano dane statystyczne udostępnione przez porty lotnicze, Urząd Lotnictwa Cywilnego, raporty i opracowania branżowe oraz naukowe. Dodatkowych informacji dostarczyła analiza współczesnych oraz historycznych zdjęć satelitarnych infrastruktury lotniskowej i okołolotniskowej portów lotniczych oraz własny systematyczny monitoring zmian sieci połączeń.

\section{RYS HISTORYCZNY}

\subsection{POLSKI RYNEK TRANSPORTU LOTNICZEGO W LATACH 80. XX W.}

W drugiej połowie lat 80. XX w. pasażerski transport lotniczy w Polsce był znacznie mniej popularny niż w krajach Europy Zachodniej. Liczba pasażerów obsłużonych w polskich portach w 1988 r. wynosiła niecałe $3 \mathrm{mln}$, a około $90 \%$ udziału w rynku przewozów miał port centralny Warszawa Okęcie (Rucińska, Ruciński, 2000). W tym czasie ruch rozkładowy odbywał się na ośmiu lotniskach. Poza warszawskim do ruchu międzynarodowego dopuszczone były porty: Kraków Balice, Gdańsk Rębiechowo, Poznań Ławica, Katowice Pyrzowice, Wrocław Strachowice, Szczecin Goleniów, Rzeszów Jasionka (Lijewski, 1986), jednak połączenia międzynarodowe tam realizowane ( $\mathrm{z}$ wyjątkiem portu w Krakowie) miały znaczenie marginalne. W portach regionalnych odbywał się głównie ruch krajowy o charakterze dowozowym do lotniska Warszawa Okęcie.
Polskie lotniska do 1987 r. były zarządzane przez Zarząd Ruchu Lotniczego i Lotnisk Komunikacyjnych (ZRLiLK). Instytucję tę rozwiązano na podstawie ustawy z 23.10.1987 r., a w zamian powołano Przedsiębiorstwo Państwowe „Porty Lotnicze” (PPPL), w ramach którego wyodrębniono Agencję Ruchu Lotniczego (ARL), odpowiedzialną za kontrolę ruchu lotniczego. W drugiej połowie lat 80 . XX w. jedynym polskim przedsiębiorstwem oferującym połączenia pasażerskie były Polskie Linie Lotnicze LOT, które ze względów politycznych i na skutek obowiązującego modelu współpracy międzynarodowej w zakresie handlu miały samoloty produkcji radzieckiej. Oprócz połączeń do stolic europejskich linie LOT wykonywały loty dalekiego zasięgu, w tym m.in. do Nowego Jorku, Chicago, Delhi oraz w systemie czarterowym do Toronto i Montrealu (Bondaryk i in., 2014).

\subsection{POLSKIE PORTY LOTNICZE} W LATACH 90. XX W. I NA POCZĄTKU XXI W.

W 1989r., wrazz początkiem przemian ustrojowych w Polsce, rozpoczął się proces dostosowywania polskiego sektora lotniczego do funkcjonowania w warunkach gospodarki wolnorynkowej. Początek lat 90. XX w. był bardzo trudny dla transportu lotniczego (Rucińska, Ruciński, 2000). Adaptacja do nowych warunków wymagała wielu zmian, w tym konieczne były inwestycje modernizujące przestarzałą infrastrukturę portów oraz wymiana floty narodowego przewoźnika (Bondaryk i in., 2014). W pierwszych latach po przemianach ustrojowych ruch pasażerski początkowo spadł - w 1990 r. łączna liczba pasażerów wyniosła 2 mln 994 tys., a w $1991 \mathrm{r}$. - 2 mln 195 tys. (rys. 1). Dopiero w 1995 r. liczba pasażerów osiągnęła wyższą wartość niż pod koniec lat 80. Udział portu Warszawa Okęcie nadal przekraczał 90\% w strukturze przewozów pasażerskich (Pijet-Migoń, 2012).

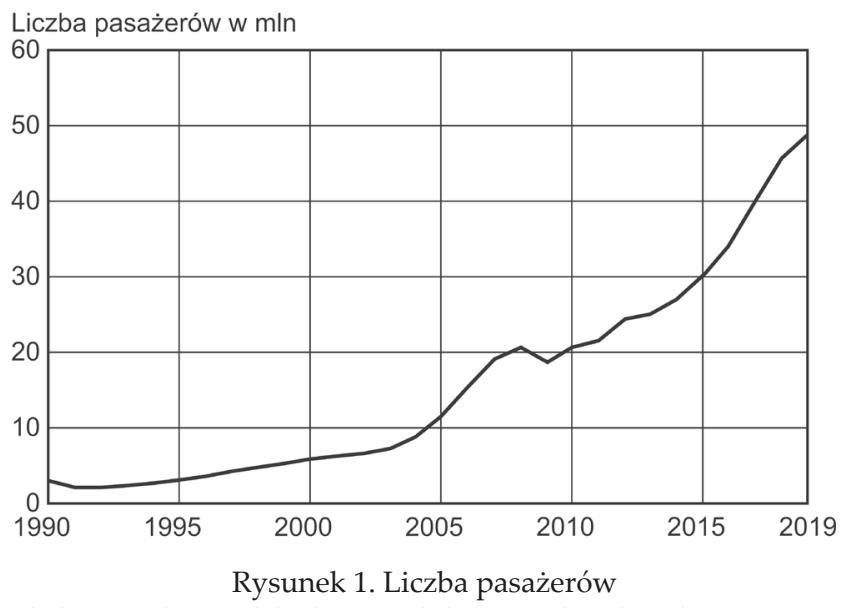

obsłużonych w polskich portach lotniczych w latach 1990-2019

Źródło: opracowanie własne na podstawie danych z Urzędu Lotnictwa Cywilnego i portów lotniczych 
W 1992 r. Polskie Linie Lotnicze LOT zostały przekształcone w jednoosobową spółkę Skarbu Państwa. Przeprowadzono wymianę samolotów radzieckich na amerykańskie samoloty średniego i dalekiego zasięgu (Boeingi 737 i 767) oraz turbośmigłowe samoloty ATR francusko-włoskiego konsorcjum, przeznaczone głównie do obsługi połączeń krajowych. W późniejszym okresie dokupiono brazylijskie samoloty Embraer do obsługi tras europejskich (Koziarski, 2007).

$\mathrm{W}$ tym czasie rozpoczęto również reorganizację struktury własnościowej portów regionalnych, które zaczęły działać jako spółki prawa handlowego. Ich udziałowcami oprócz Przedsiębiorstwa Państwowego "Porty Lotnicze” zostały Skarb Państwa, samorządy terytorialne oraz kapitał lokalny. Pod zarządem Przedsiębiorstwa Państwowego „Porty Lotnicze” pozostały lotniska w Warszawie, Rzeszowie i Zielonej Górze (Liwiński, 2006).

Zarządy portów regionalnych podjęły starania o wprowadzenie do oferty połączeń międzynarodowych. W 1993 r. niemieckie linie Lufthansa zapoczątkowały regularne loty z portu Katowice Pyrzowice do Frankfurtu, linie skandynawskie SAS z Gdańska do Kopenhagi, niemiecki przewoźnik Eurowings z Wrocławia do Frankfurtu oraz PLL LOT z Wrocławia przez Poznań do Düsseldorfu. W następnych latach rozbudowywano siatkę połączeń. Rozwijał się również wakacyjny ruch czarterowy. Połączenia regularne zostały przywrócone na lotniskach w Bydgoszczy, Łodzi i Zielonej Górze. W 2003 r. w Polsce funkcjonowało 10 portów regionalnych (rys. 2), a ich udział w strukturze przewozów pasażerskich wynosił 27\% (rys. 3). W 2003 r.

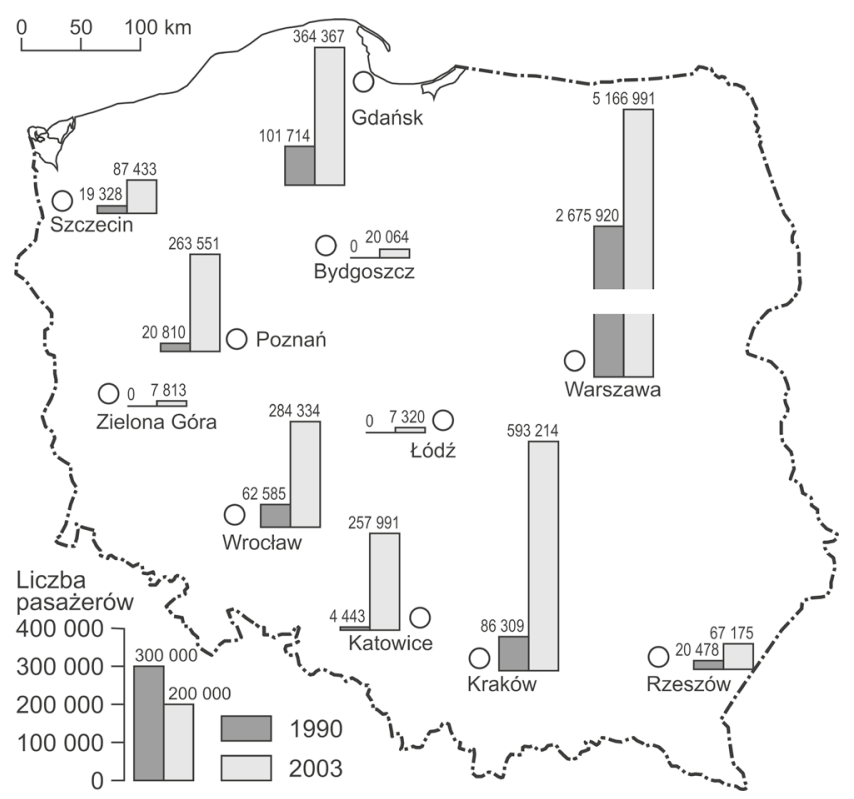

Rysunek 2. Porównanie wielkości ruchu pasażerskiego w polskich portach w 1990 i $2003 \mathrm{r}$.

Źródło: opracowanie własne na podstawie danych z Urzędu Lotnictwa Cywilnego i portów lotniczych

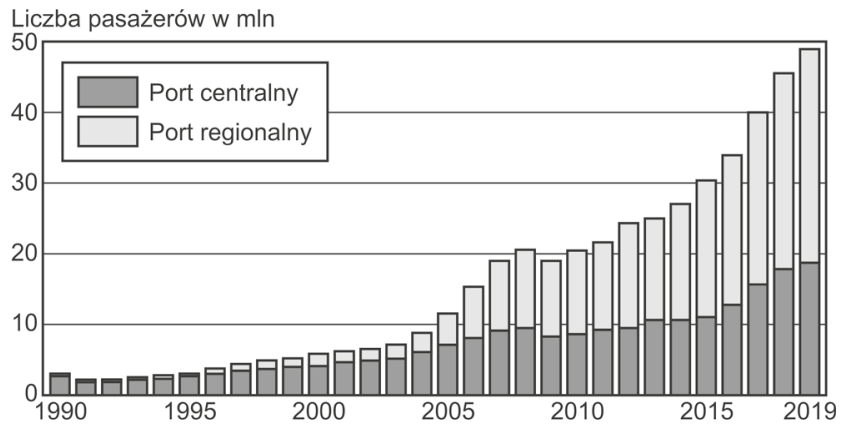

Rysunek 3. Udział portu centralnego Warszawa Okęcie w strukturze przewozów pasażerskich w latach 1990-2019

Źródło: opracowanie własne na podstawie danych z Urzędu Lotnictwa Cywilnego i portów lotniczych

najbardziej popularne, wśród portów regionalnych, było lotnisko w Krakowie, na którym obsłużono 593 tys. pasażerów. Na kolejnych miejscach znalazły się porty w Gdańsku (364 tys.), Wrocławiu (284 tys.), Poznaniu (267 tys.), Katowicach (258 tys.), Szczecinie (87 tys.), Rzeszowie (67 tys.), Bydgoszczy (20 tys.), Zielonej Górze (7,8 tys.), Łodzi (7,3 tys.). Tuż przed przystąpieniem Polski do Unii Europejskiej (UE) pierwszy polski przewoźnik niskokosztowy Air Polonia zaczął oferować połączenia międzynarodowe z portów regionalnych (Pijet-Migoń, 2016).

\subsection{TRANSPORT LOTNICZY W POLSCE PO AKCESIE DO UNII EUROPEJSKIEJ}

Przystąpienie Polski do Unii Europejskiej oraz związana z tym konieczność liberalizacji rynku transportu lotniczego i przyjęcie polityki „otwartego nieba” spowodowały szereg zmian. Do najbardziej widocznych należał wzrost liczby pasażerów (rys. 4), ekspansja przewoźników niskokosztowych oraz wzrost znaczenia portów regionalnych (Jankiewicz, Huderek-Glapska, 2016; Pijet-Migoń, 2012). Okres 15 lat od przystąpienia Polski do UE nie był czasem równomiernego rozwoju portów regionalnych. Można w nim wyróżnić trzy fazy (rys. 5) (Pijet-Migoń, 2019). Pierwsza faza, przypadająca na lata 2004-2008, charakteryzowała się ekspansją przewoźników niskokosztowych, bardzo silną konkurencją na rynku, a nawet wojnami cenowymi. Druga faza, na którą nałożył się kryzys gospodarczy, była okresem konsolidacji rynku. Doszło do licznych bankructw linii lotniczych, wiele połączeń zostało zlikwidowanych lub zawieszonych i nastąpił wyraźny podział rynku wśród przewoźników niskokosztowych. W Polsce największe znaczenie w tym segmencie zyskały linie lotnicze Ryanair i Wizzair. W 2012 r. rozpoczęła się trzecia faza, ponownie można było obserwować dużą dynamikę wzrostu ruchu pasażerskiego, proces ten został jednak dramatycznie przerwany przez pandemię wirusa SARS-CoV-2 w 2020 r. Faza trzecia charakteryzowała się 


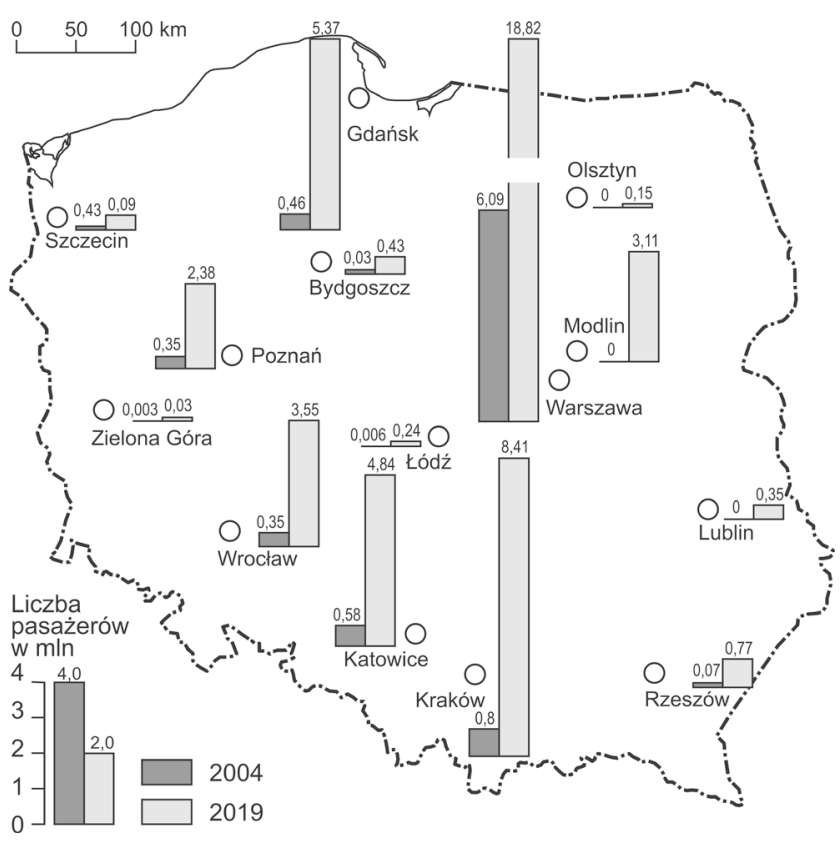

Rysunek 4. Wielkości ruchu pasażerskiego w polskich portach w 2004 i 2019 r.

Źródło: opracowanie własne na podstawie danych z Urzędu Lotnictwa Cywilnego i portów lotniczych

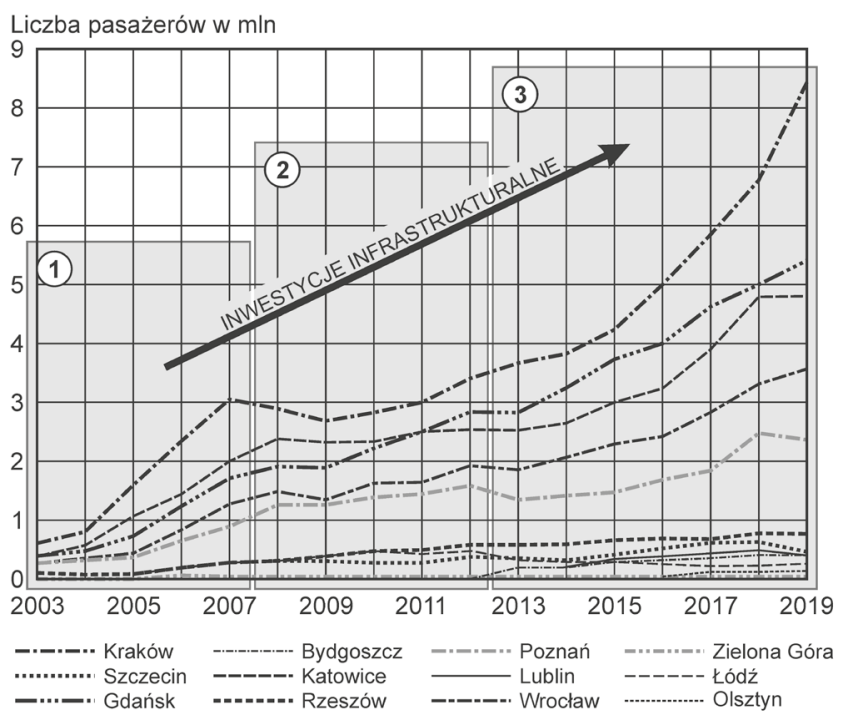

Rysunek 5. Trzy fazy rozwoju portów regionalnych po akcesie Polski do Unii Europejskiej

Źródło: opracowanie własne na podstawie danych z Urzędu Lotnictwa Cywilnego

poszukiwaniem nisz rynkowych oraz wzrostem liczby przewoźników tradycyjnych w portach regionalnych.

W pierwszej fazie tempo wzrostu liczby pasażerów, liczone $\mathrm{w}$ stosunku do roku poprzedniego, było na poziomie 24-34\% (w 2004 r. wynosiło $24 \%$, w 2005 r. 30\%, w 2006 r. 33,6\%, a w 2007 r. 24,4\%). Szczególnie szybko wzrastała liczba pasażerów w portach regionalnych. Działo się tak głównie za sprawą przewoźników niskokosztowych, którzy zgodnie ze swoją strategią wybierali znacznie tańsze i mniej zatłoczone porty regionalne, równocześnie licząc na bezpośrednie i pośrednie wsparcie finansowe ze strony zarządów portów i władz samorządowych - zainteresowanych pozyskiwaniem nowych, bezpośrednich połączeń lotniczych. $\mathrm{W}$ ciągu pierwszych pięciu lat przynależności Polski do Unii Europejskiej liczba pasażerów wzrosła niemal trzykrotnie. W 2003 r. wynosiła 7,1 mln, a w 2008 r., mimo światowego kryzysu gospodarczego, przekroczyła 20,6 mln pasażerów. W przypadku portów regionalnych przyrost liczby pasażerów był jeszcze większy. W 2008 r. w porcie lotniczym w Krakowie obsłużono prawie 2,9 $\mathrm{mln}$ pasażerów, w Katowicach 2,4 $\mathrm{mln}$, w Gdańsku 1,9 mln. Ponad milion pasażerów skorzystało także z lotnisk we Wrocławiu (1 mln 480 tys.) i Poznaniu (1 mln 329 tys.). Połączenia międzynarodowe utworzono we wszystkich portach regionalnych, z wyjątkiem Zielonej Góry. Do zwiększenia popularności podróży samolotem przyczynił się niewątpliwie wzrost dostępności cenowej i czasowej transportu lotniczego. Na to nałożyła się większa mobilność polskich obywateli, wynikająca między innymi z otwarcia europejskich rynków pracy, rozwoju gospodarczego i turystyki.

Wzrosła znacząco nie tylko liczba pasażerów, ale również liczba przewoźników i oferowanych kierunków połączeń z poszczególnych portów. Doszło również do zwiększenia częstotliwości połączeń z niektórymi miastami, a tym samym zmieniła się dostępność lotnicza, rozumiana jako oferta podażowa poszczególnych portów. Warto zauważyć, że częstotliwość połączeń ma szczególne znaczenie w ruchu biznesowym. Dla lepszego zobrazowania dostępności lotniczej poszczególnych miast autorka zaproponowała wskaź-

Tabela 1. Zmiana wartości wskaźnika dostępności lotniczej $\mathrm{w}$ polskich portach

\begin{tabular}{|l|c|c|c|c|}
\hline Port lotniczy & 2003 & 2008 & 2013 & 2019 \\
\hline Warszawa & 19 & 21 & 21 & 23 \\
\hline Kraków & 6 & 9 & 8 & 12 \\
\hline Katowice & 3 & 7 & 6 & 7 \\
\hline Gdańsk & 4 & 7 & 8 & 9 \\
\hline Wrocław & 4 & 6 & 6 & 7 \\
\hline Poznań & 3 & 5 & 5 & 5 \\
\hline Łódź & 1 & 3 & 3 & 2 \\
\hline Rzeszów & 1 & 3 & 3 & 3 \\
\hline Szczecin & 2 & 2 & 3 & 3 \\
\hline Bydgoszcz & 1 & 4 & 3 & 3 \\
\hline $\begin{array}{l}\text { Zielona } \\
\text { Góra }\end{array}$ & 1 & 1 & 1 & 1 \\
\hline Modlin & - & - & 3 & 6 \\
\hline Lublin & - & - & 2 & 2 \\
\hline Olsztyn & - & - & - & 2 \\
\hline
\end{tabular}

Źródło: opracowanie własne. Wyliczenia wykonane na postawie rozkładów połączeń. 
nik dostępności lotniczej (Pijet-Migoń, 2012), utworzony na wzór wskaźników stosowanych w bibliometrii ( $\mathrm{zw}$. wskaźnik Hirscha). Wskaźnik ten wyrażony jest liczbą całkowitą X, która oznacza, że x miast ma przynajmniej x połączeń do danego portu w ciągu tygodnia. Im wyższa wartość wskaźnika, tym większa siła powiązań między miastami i bardziej rozwinięte funkcje metropolitalne ośrodka. Bardzo istotnie wskaźnik ten zmienił się w przypadku największych portów regionalnych (tab. 1). W przypadku Krakowa wartość wskaźnika zwiększyła się z 6 w 2003 r. do 12 w 2019 r. Oznacza to, że tuż przed przystąpieniem Polski do UE port lotniczy w Krakowie miał połączenia z 6 miastami, realizowane co najmniej 6 razy w tygodniu, natomiast w 2019 r. realizował loty do 12 miast, wykonując 12 lub więcej połączeń $\mathrm{w}$ tygodniu. $\mathrm{W}$ przypadku Gdańska wskaźnik dostępności lotniczej zwiększył się z 4 do 9, Katowic-z 3 do 7, Wrocławia-z 4 do7, Poznania $-\mathrm{z} 3$ do 5 .

\section{ROZBUDOWA INFRASTRUKTURY LOTNISKOWEJ I OKOŁOLOTNISKOWEJ}

W celu podniesienia komfortu obsługi zwiększającej się liczby pasażerów i poprawy przepustowości portów niezbędne były inwestycje infrastrukturalne. Najwięcej przeprowadzono ich w latach 2009-2013, a więc w drugiej fazie rozwoju rynku lotniczego, ale decyzje o przedsięwzięciach zapadły już wcześniej - w czasie dynamicznego wzrostu w fazie pierwszej. Inwestycje związane były głównie z infrastrukturą lotniskową i okołolotniskową (tab. 2). Dzięki wsparciu funduszy unijnych rozbudowano lub wybudowano nowe terminale lotnicze. Okazałe terminale powstały m.in. we Wrocławiu, Gdańsku, Szczecinie, Bydgoszczy (fot. 1-4). W większości portów dodatkowo zmodernizowano i rozbudowano pozostałą infrastrukturę lotniskową

Tabela 2. Zestawienie głównych inwestycji infrastrukturalnych w polskich portach lotniczych w latach 1989-2019

\begin{tabular}{|c|c|c|}
\hline Port lotniczy & 1989-2004 & 2005-2019 \\
\hline Warszawa & $\begin{array}{l}\text { 1990-1992 - budowa nowego terminalu; } \\
2002 \text { - przebudowa terminalu krajowego }\end{array}$ & $\begin{array}{l}\text { 2004-2005 - adaptacja hali przylotów z lat 70. XX w. na terminal } \\
\text { linii niskokosztowych; } \\
\text { 2005-2009 - budowa nowego terminalu pasażerskiego; } \\
\text { 2009-2012 - rozbudowa infrastruktury hotelowej przy lotnisku; } \\
\text { 2010-2011 - remonty dróg startowych, rozbudowa płyt } \\
\text { postojowych i dróg kołowania; } \\
\text { 2012 - uruchomienie połączenia kolejowego z centrum miasta; } \\
\text { 2014 - nowa płyta postojowa dla samolotów cargo; } \\
\text { 2015 - remont terminalu z lat 90. i integracja z nowym }\end{array}$ \\
\hline Kraków & $\begin{array}{l}1993 \text { - oddanie do użytku pierwszej części } \\
\text { nowego terminalu pasażerskiego; } \\
1995 \text { - generalny remont i wydłużenie } \\
\text { drogi startowej, instalacja nowego systemu } \\
\text { oświetlenia; } \\
2000 \text { - nowy terminal cargo; } \\
2001 \text { - nowy terminal międzynarodowy }\end{array}$ & $\begin{array}{l}2006 \text { - połączenie kolejowe z centrum miasta; } \\
2007 \text { - otwarcie nowej części terminalu międzynarodowego T1; } \\
2010 \text { - otwarcie parkingu wielopoziomowego; } \\
2011 \text { - modernizacja wewnętrznego układu drogowego portu; } \\
2015 \text { - oddanie do użytku nowej części terminalu pasażerskiego; } \\
2018 \text { - uruchomienie nowej wieży kontroli lotów } \\
\text { (45 m wysokości) }\end{array}$ \\
\hline Katowice & $\begin{array}{l}1994 \text { - nowy terminal pasażerski; } \\
1999 \text { - nowe budynki terminalu cargo; } \\
2000 \text { - rozbudowa płyt postojowych i drogi } \\
\text { startowej }\end{array}$ & $\begin{array}{l}2006 \text { - ulepszenie dróg dojazdowych do portu lotniczego; } \\
2007 \text { - otwarcie terminalu B; } \\
2008 \text { - nowy system ILS kat. I; } \\
2011 \text { - modernizacja hangaru technicznego i remont terminalu A; } \\
2013 \text { - modernizacja bazy cargo; } \\
2015 \text { - oddanie do użytku terminalu C i nowej drogi startowej } \\
\text { o długości } 3200 \text { m, rozbudowa płyt postojowych i modernizacja } \\
\text { dróg kołowania; } \\
\text { 2016 - dalsza rozbudowa części lotniska służącej do obsługi } \\
\text { towarowej }\end{array}$ \\
\hline Gdańsk & $\begin{array}{l}1997 \text { - oddanie do użytku nowego terminalu } \\
\text { pasażerskiego; } \\
1999 \text { - budowa nowej wieży kontroli lotów }\end{array}$ & $\begin{array}{l}\text { 2009-2012 - budowa nowej drogi kołowania, płyty postojowej, } \\
\text { dróg szybkiego zjazdu, płyty odladzania i terminalu } \\
\text { pasażerskiego T2; } \\
2015 \text { - uruchomienie dojazdu na lotnisko Pomorską Koleją Me- } \\
\text { tropolitalna; } \\
2018 \text { - oddanie do użytku terminalu cargo; } \\
2019 \text { - rozpoczęcie budowy biurowców Airport City Gdańsk }\end{array}$ \\
\hline Wrocław & $\begin{array}{l}1997 \text { - rozbudowa terminalu pasażerskiego } \\
\text { i cargo; } \\
2001 \text { - nowa wieża kontroli lotów }\end{array}$ & $\begin{array}{l}2012 \text { - otwarcie nowego terminalu pasażerskiego (w innym } \\
\text { miejscu), budowa nowych płyt postojowych, dróg kołowania } \\
\text { i parkingów oraz poszerzenie ulicy dojazdowej }\end{array}$ \\
\hline
\end{tabular}


Tabela 2. (cd.)

\begin{tabular}{|c|c|c|}
\hline Port lotniczy & 1989-2004 & 2005-2019 \\
\hline Poznań & $\begin{array}{l}1997 \text { - rozbudowa terminalu lotniczego, } \\
\text { nowy parking; } \\
2000 \text { - budowa nowego terminalu, } \\
\text { rozbudowa płyty postojowej; } \\
2003 \text { - oddanie do użytku zmodernizowanego } \\
\text { terminalu General Aviation; } \\
2004 \text { - nowa droga kołowania }\end{array}$ & $\begin{array}{l}2012 \text { - otwarcie terminalu przylotów T3, budowa nowej drogi } \\
\text { kołowania oraz rozbudowa płyty postojowej; } \\
2013 \text { - otwarcie terminalu pasażerskiego po rozbudowie } \\
\text { i modernizacji; } \\
2014 \text { - nowa wieża kontroli rejsów }\end{array}$ \\
\hline Łódź & $\begin{array}{l}1996 \text { - wydłużenie drogi startowej z } 1220 \mathrm{~m} \\
\text { do } 1440 \mathrm{~m} \text { i przebudowanie drogi } \\
\text { kołowania, otwarcie nowego terminalu } \\
\text { pasażerskiego }\end{array}$ & $\begin{array}{l}2005 \text { - wydłużenie drogi startowej do } 2100 \text { m; } \\
2007 \text { - powiększenie płyty postojowej; } \\
2009 \text { - nowy terminal cargo; } \\
2012 \text { - nowy terminal pasażerski }\end{array}$ \\
\hline Rzeszów & $\begin{array}{l}\text { Początek lat 90. - budowa nowej hali } \\
\text { przylotów-odlotów }\end{array}$ & $\begin{array}{l}\text { 2004-2005 - wydłużenie drogi startowej do } 3200 \text { m; } \\
\text { 2005 - oddanie do użytku drugiej płyty postojowej; } \\
\text { 2010-2011- przebudowa płyt postojowych, dróg kołowania, nowe } \\
\text { hangary; } \\
\text { 2013 - oddanie do użytku nowego terminalu pasażerskiego; } \\
\text { 2014 - budowa Ośrodka Kontroli Ruchu Lotniczego }\end{array}$ \\
\hline Szczecin & $\begin{array}{l}1998 \text { - remont drogi startowej; } \\
2001 \text { - otwarcie nowego terminalu odlotów }\end{array}$ & $\begin{array}{l}2005 \text { - rozbudowa terminalu pasażerskiego; } \\
2010 \text { - modernizacja płyty postojowej, dróg kołowania i drogi } \\
\text { startowej; } \\
2013 \text { - uruchomienie przystanku kolejowego Port Lotniczy, } \\
\text { obsługującego połączenia ze Szczecinem Głównym i Kołobrzegiem; } \\
2015 \text { - kolejna modernizacja drogi startowej }\end{array}$ \\
\hline Bydgoszcz & $\begin{array}{l}1996 \text { - przywrócenie lotów cywilnych } \\
\text { (połączenia do Warszawy) }\end{array}$ & $\begin{array}{l}2004 \text { - oddanie do użytku nowego terminalu pasażerskiego; } \\
2012 \text { - remont drogi startowej; } \\
2013 \text { - remont płyty postojowej i budowa nowej radiolatarni }\end{array}$ \\
\hline Zielona Góra & $\begin{array}{l}1989 \text { - modernizacja drogi startowej; } \\
2001 \text { - modernizacja terminalu } \\
\text { i wznowienie połączeń z Warszawą }\end{array}$ & $\begin{array}{l}2014 \text { - wyposażenie lotniska w system wspomagania lądowania } \\
\text { ILS kat. I; } \\
2015 \text { - budowa nowej hali przylotów }\end{array}$ \\
\hline Modlin & lotnisko pełniło wyłącznie funkcje wojskowe & $\begin{array}{l}\text { 2010 - zmiana funkcji z wojskowej na cywilną i początek } \\
\text { modernizacji lotniska; } \\
\text { 2012 - rozpoczęcie obsługi lotów pasażerskich (zawieszonych od } \\
\text { 22.12.2012 r. do } 30.09 .2013 \text { r. ze względu na konieczność remontu } \\
\text { wadliwie wykonanego pasa startowego) }\end{array}$ \\
\hline Lublin & & $\begin{array}{l}2008 \text { - rozpoczęcie prac związanych z budową lotniska } \\
\text { (wycięcie ok. } 100 \text { ha lasu, splantowanie terenu); } \\
2010 \text { - początek budowy; } \\
2012 \text { (grudzień) - rozpoczęcie działalności }\end{array}$ \\
\hline Olsztyn & $\begin{array}{l}\text { W latach 1996-2003 lotnisko łączyło funkcję } \\
\text { wojskową z cywilną }\end{array}$ & $\begin{array}{l}\text { 2007-2015 - modernizacja i rozbudowa lotniska, w tym budowa } \\
\text { nowego terminalu oraz przystanku kolejowego Szymany Lotnisko; } \\
\text { 2016 - rozpoczęcie działalności jako port cywilny }\end{array}$ \\
\hline
\end{tabular}

Źródło: opracowanie własne na postawie danych ze stron internetowych portów lotniczych oraz Sipiński, Cybulak, Plachta (2016).

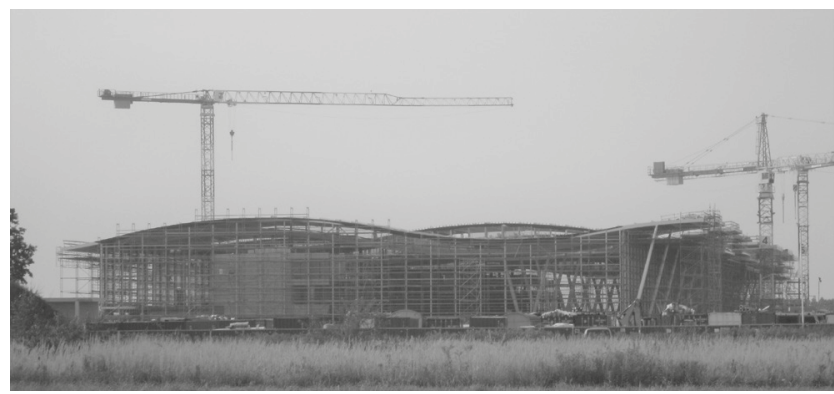

Fotografia 1. Budowa nowego terminalu we Wrocławiu Źródło: fotografia własna

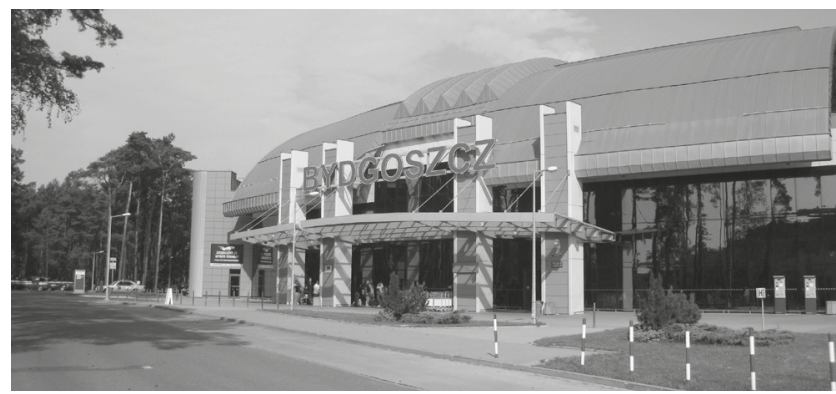

Fotografia 2. Terminal w Bydgoszczy Źródło: fotografia własna 


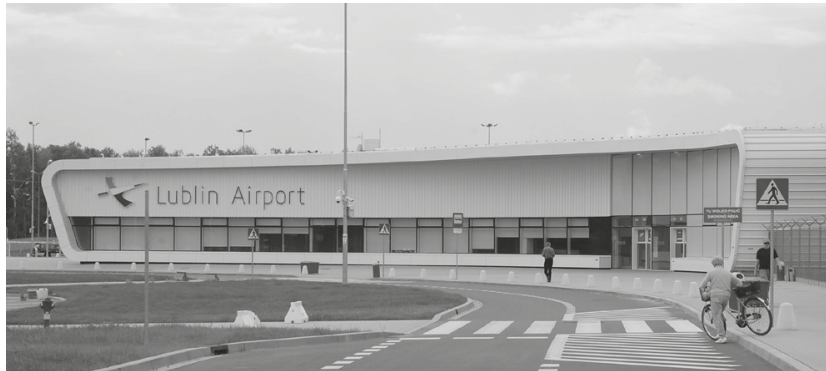

Fotografia 3. Terminal w Lublinie Źródło: fotografia własna

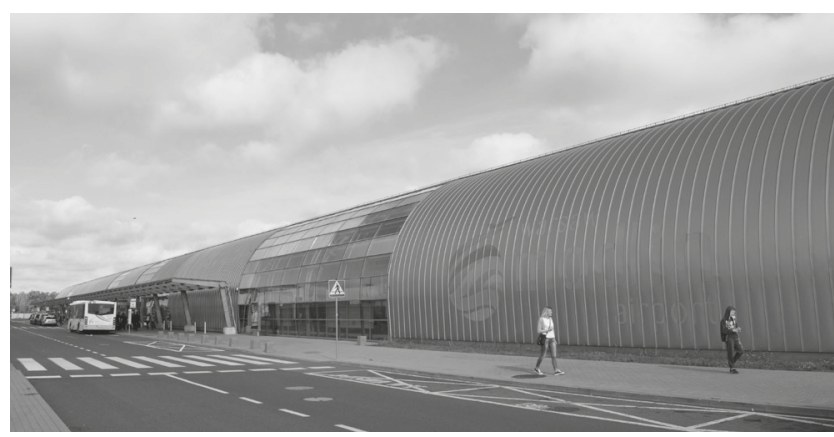

Fotografia 4. Terminal w Modlinie Źródło: fotografia własna

obejmującą m.in. drogi kołowania, płyty postojowe, systemy nawigacyjne i oświetlenia.

Wraz z szybkim wzrostem liczby pasażerów podjęto również decyzje o budowie nowych lotnisk lub zmianie funkcji z dotychczasowej wojskowej na cywilną. Nowe lotnisko dla wschodniej Polski zostało oddane do użytku w 2012 r. w Świdniku pod Lublinem (Hawlena, 2016). W tym samym roku do ruchu cywilnego zaadaptowano dawne lotnisko wojskowe w Modlinie. Port ten stał się lotniskiem uzupełniającym dla Warszawy, specjalizującym się w obsłudze ruchu niskokosztowego, czarterowego i towarowego. W 2016 r., po modernizacji i przebudowie, działalność wznowiło lotnisko Szymany, które zmieniło nazwę marketingową na Olsztyn-Mazury, chcąc w ten sposób podkreślić swoje znaczenie w obsłudze głównego miasta regionu i rozpoznawalnego, także poza Polską, popularnego obszaru turystycznego. Funkcję wojskową na cywilną zmieniły po przebudowie także lotniska w Gdyni Kosakowie i Radomiu. Nie były to jednak udane inwestycje. Lotnisko w Kosakowie, które miało uzupełniać port lotniczy w Gdańsku, nie mogło rozpocząć działalności, ponieważ Komisja Europejska podważyła legalność przyznanej pomocy publicznej na jego rozbudowę (Rydzkowski, 2014). Inwestycja nie została ukończona i spółka Port Lotniczy Gdynia-Kosakowo ogłosiła upadłość. Port lotniczy w Radomiu został otwarty dla ruchu cywilnego w 2012 r., jednak ze względu na bardzo małe zainteresowanie przewoźników i pasażerów jego działalność została zawieszona w 2014 r.

\section{ZMIANY \\ W UKŁADZIE TRANSPORTOWYM \\ W SĄSIEDZTWIE PORTÓW LOTNICZYCH I POWIAZZANE PRZEOBRAŻENIA W ZAGOSPODAROWANIU PRZESTRZENNYM}

Ze względu na lokalizację portów lotniczych, często w dość dużym oddaleniu od centrów miast, bardzo istotne jest włączanie lotnisk do całościowego systemu transportowego. Intermodalność w odniesieniu do portu lotniczego rozpatrywana jest $\mathrm{w}$ dwóch płaszczyznach: dostępności oraz integracji z innymi gałęziami transportu (Huderek-Glapska, 2010). Dostępność do portu lotniczego jest jednym z instrumentów wspierania konkurencyjności portu i wpływa na wielkość obszaru jego ciążenia (Bednarczyk, Grabińska, 2015; Rosik, Komornicki, Goliszek, Stępniak, Pomianowski, 2017; Tłoczyński, 2016). Istotnym elementem intermodalności podróży lotniczych jest możliwość skorzystania z dojazdu do portu transportem publicznym, skoordynowanym $z$ ofertą przelotów (Kołoś, Taczanowski, Trzepacz, 2012).

W celu poprawienia czasu i komfortu dojazdu do portów lotniczych rozpoczęto przebudowy dróg dojazdowych oraz wprowadzono zmiany w układzie dróg i parkingów w najbliższym sąsiedztwie nowych terminali. Tak było m.in. w przypadku poszerzania i budowy dróg dojazdowych do nowych terminali pasażerskich we Wrocławiu (fot. 5) i Gdańsku (fot. 6). W Gdańsku do portu lotniczego doprowadzona została również linia kolejowa.

W sześciu miastach uruchomiono połączenia kolejowe umożliwiające dogodne dotarcie do lotnisk, wykorzystujące rozbudowaną lub odtworzoną starszą infrastrukturę (tab. 3). W wielu miastach (m.in. w Modlinie, Wrocławiu, Krakowie) dodano nowe połączenia autobusowe, umożliwiające podróż z centrum bezpośrednio na lotnisko lub wydłużono trasy istniejących już wcześniej linii komunikacji miejskiej (Pomykała, Raczyński, Graff, Bużałek, 2019).

Doprowadzenie linii kolejowej do lotniska, poprawa rozwiązań w komunikacji drogowej i dogodne włączenie drogi dojazdowej na lotnisko do systemu dróg szybkiego ruchu sprawiły, że w przypadku kilku portów (np. Krakowa i Gdańska) można mówić o początkach tworzenia węzłów multimodalnych, a to z kolei sprzyja lokalizowaniu $\mathrm{w}$ ich pobliżu baz firm o charakterze spedycyjnym i logistycznym (Stangel, 2013). Poprawa integracji portu lotniczego z siecią kolejową poprzez rozbudowę kolei aglomeracyjnej, planowana jest również w Rzeszowie (Gierczak-Korzeniowska, 2020).

W sąsiedztwie portów lotniczych zaczęto budować nowe hotele, pensjonaty, obiekty konferencyjne, a nawet kompleksy biurowe i handlowe, co daje początek 

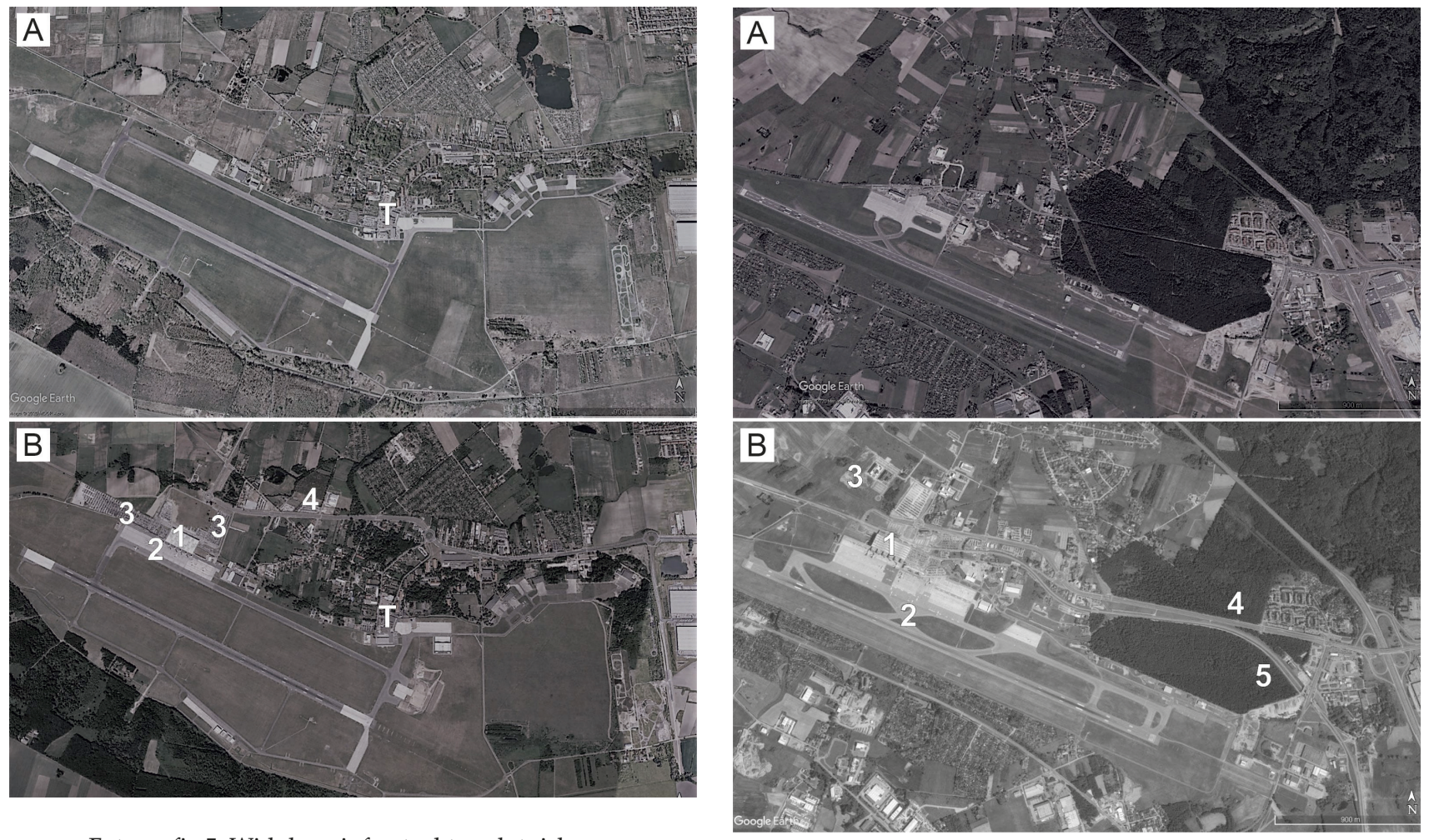

Fotografia 5. Widok na infrastrukturę lotniskową i okołolotniskową oraz układ dróg dojazdowych we Wrocławiu w 2006 r. (A) i w 2018 r. (B)

Objaśnienia: T - dawny budynek terminalu, obecnie terminal General Aviation; 1 - budynek nowego dworca lotniczego;

2 - nowa płyta postojowa; 3 - nowe parkingi; 4 - poszerzona i wydłużona ulica Graniczna. Źródło: opracowanie własne na podstawie zasobów Google Earth (2020)

Fotografia 6. Widok na infrastrukturę lotniskową i okołolotniskową oraz układ komunikacyjny w Gdańsku w 2006 r. (A) i w 2019 r. (B)

Objaśnienia: 1 - nowy terminal; 2 - nowy układ dróg kołowania; 3 - BCB Business Park; 4 - nowy odcinek ulicy Słowackiego;

5 - Pomorska Kolej Metropolitalna.

Źródło: opracowanie własne

na podstawie zasobów Google Earth (2020)

Tabela 3. Połączenia kolejowe do portów lotniczych

\begin{tabular}{|l|c|c|c|}
\hline \multicolumn{1}{|c|}{ Port lotniczy } & $\begin{array}{c}\text { Odległość od centrum } \\
\mathrm{w} \mathrm{km}\end{array}$ & $\begin{array}{c}\text { Data uruchomienia } \\
\text { połączenia kolejowego }\end{array}$ & $\begin{array}{c}\text { Czas dojazdu z centrum miasta do lotniska } \\
\text { w minutach }\end{array}$ \\
\hline Warszawa Okęcie & 12,5 & 2012 & 23 \\
\hline Kraków Balice & 10,8 & 2006 & 19 \\
\hline Gdańsk & 16,0 & 2015 & 30 \\
\hline Lublin & 13,0 & 2012 & 30 \\
\hline Szczecin Goleniów & 42,0 & 2013 & 56 \\
\hline Olsztyn-Mazury & 55,0 & 2016 & 30 \\
\hline
\end{tabular}

Źródło: Pomykała, Raczyński, Graff, Bużałek (2019).

tworzeniu airport cities (Rucińska, Ruciński, 2017; Stangel, 2014; Wróbel, 2012). Proces ten najbardziej widoczny jest w pobliżu portu lotniczego Warszawa Okęcie, ale również w innych miastach, np. w pobliżu terminalu T2 portu lotniczego w Gdańsku rozpoczęto inwestycję nazwaną Airport City Gdańsk (Wach-Kloskowska, 2020). Ponadto początki rozwoju dodatkowych funkcji usługowych w pobliżu lotnisk można obserwować we Wrocławiu, Poznaniu (Nowak, Huderek-Glapska, 2019) i Rzeszowie (Gierczak-Korzeniowska, 2016).

\section{ROZWÓJ TURYSTYKI PRZYJAZDOWEJ I DALSZE ZMIANY FUNKCJONALNE I SPOŁECZNE MIAST}

Wraz ze zwiększeniem oferty połączeń oraz wzrostem dostępności, także cenowej, transportu lotniczego nastąpił gwałtowny rozwój turystyki wyjazdowej oraz przyjazdowej, mającej większe znaczenie dla miast i regionów turystycznych. Upowszechnienie się turystyki, 
zwłaszcza krótkoterminowej typu City Breaks i biznesowej, obejmującej udział w kongresach, konferencjach i różnego typu wydarzeniach, nastąpiło wraz z ekspansją przewoźników niskokosztowych (Awedyk, Markiewicz, Weltrowska, 2013; Hawlena, 2012b; Pijet-Migoń, 2014). Wzrost liczby turystów oraz prognozy dotyczące rozwoju turystyki miały dalsze konsekwencje $\mathrm{w}$ postaci rozbudowy infrastruktury konferencyjnej (Borodako i in., 2019; Celuch, 2018), hotelowej i nowych form zakwaterowania, w tym wynajmu krótkoterminowego mieszkań. Turystyka przyjazdowa zaczęła zyskiwać na znaczeniu prawie we wszystkich miastach, w których działają porty lotnicze. Do jej rozwoju przyczyniały się zintensyfikowane kampanie promocyjne prowadzone przez miasta, organizacje turystyczne oraz przedsiębiorstwa lotnicze. Wyraźny wzrost liczby turystów widoczny był w Warszawie, Krakowie, Gdańsku, Wrocławiu i Poznaniu. W latach 2016-2019 ruch turystyczny był tak duży, że zaczęto obserwować zjawisko nazwane turystyfikacją zabytkowych centrów, prowadzące do zmian funkcjonalnych i społecznych (Kowalczyk-Anioł, 2019a; Kubicki, 2017), a w przypadku Warszawy i Krakowa nawet zjawisko overtourismu, przyczyniające się do powstawania konfliktów społecznych pomiędzy stałymi mieszkańcami miast a turystami (Fedyk, Sołtysik, Olearnik, Barwicka, Mucha, 2020; Szromek, Kruczek, Walas, 2020; Zmyślony, Pilarczyk, 2020). Nadmierny rozwój turystyki w ścisłych centrach miast przyczyniał się do niekorzystnych, z punktu widzenia mieszkańców, zmian. Powodowały one obniżenie komfortu życia, wynikające z zatłoczenia, nadmiernego hałasu, zaśmiecenia (zwłaszcza gdy organizowane były duże wydarzenia), wzrostu cen, wyparcia niektórych tradycyjnych usług z centrum oraz nadmiernej komercjalizacji, która prowadzi do utraty autentyczności i uroku niektórych dzielnic (Kubicki, 2017; Kowalczyk-Anioł, 2019b; Walas, 2019).

\section{WPŁYW PORTU LOTNICZEGO NA GOSPODARKĘ MIAST I REGIONÓW}

Transport lotniczy jest uważany za istotny czynnik dynamizujący procesy rynkowe (Button, Taylor, 2000; Graham, 2008; Pancer-Cybulska, Olipra, 2016; Tłoczyński, 2016). Pomiędzy rozwojem gospodarczym i społecznym a transportem lotniczym istnieją silne zależności (Halpern, Brathen, 2011; Sonnenburg, Braun, 2017). Przeprowadzone w ostatnich latach liczne badania na temat funkcjonowania polskich portów regionalnych (Bednarczyk, Grabińska, 2015; Huderek-Glapska, 2019; Pancer-Cybulska, Olipra, Cybulski, Surówka, 2014; Rekowski, 2011; Tłoczyński, 2016; Trzepacz, 2014) potwierdziły istotny wpływ portów lotniczych na gospodarkę miast i regionu. Jednakże należy brać pod uwagę, że inwestycje lotniskowe wymagają wniesienia bardzo dużego kapitału, a funkcjonowanie portów jest kosztowne, w związku z tym trzeba pamiętać o problemie ich rentowności (Augustyniak, 2017). Nie wszystkie, przeprowadzone $\mathrm{w}$ omawianym okresie, inwestycje infrastrukturalne związane z lotniczym transportem pasażerskim okazały się trafne. Niektóre porty (np. lotnisko w Radomiu) generują jedynie wydatki. Kilka mniejszych portów regionalnych (np. lotniska w Zielonej Górze i Bydgoszczy) ma problemy z rentownością $\mathrm{i}$ ich utrzymanie wymaga dofinansowania $\mathrm{z}$ budżetu regionów (Augustyniak, 2017).

W literaturze przedmiotu wpływ portu lotniczego na gospodarkę miasta i regionu dzieli się na: bezpośredni, pośredni, indukowany i stymulowany, zwany również katalitycznym (ACI Europe, 2004; Huderek-Glapska, 2011; Pancer-Cybulska, Olipra, Cybulski, Surówka, 2014). Wpływ bezpośredni obejmuje zatrudnienie oraz przychody $\mathrm{w}$ przedsiębiorstwach ściśle powiązanych z działalnością lotniczą. Wpływ pośredni dotyczy wielkości zatrudnienia oraz przychodów generowanych w obrębie łańcucha dostaw towarów i usług dla portu lotniczego, czyli np. placówek handlowych, firm porządkowych. Wpływ indukowany obejmuje przychody w obrębie gospodarki danego obszaru w wyniku wydatków ponoszonych przez przedsiębiorstwa i ich pracowników, związanych bezpośrednio lub pośrednio z branżą lotniczą. Wpływ stymulowany (katalityczny) jest najtrudniejszy do oszacowania, dotyczy zatrudnienia oraz przychodów generowanych w obrębie gospodarki danego miasta i regionu w związku z wpływem portu lotniczego na wzrost aktywności gospodarczej miejsca. Aktywność ta związana jest z inwestycjami, które zostały zrealizowane $\mathrm{w}$ danej lokalizacji ze względu na obecność portu lotniczego i jego dostępność oraz rozwijającą się turystykę. Dostępność komunikacyjna, w tym dogodne połączenia lotnicze, wpłynęły na ostateczną decyzję o lokalizacji wielu międzynarodowych przedsiębiorstw oraz na wybór niektórych polskich miast jako miejsc organizacji dużych międzynarodowych imprez o charakterze sportowym (np. Euro 2012, World Games we Wrocławiu w 2017 r.), kulturalnym (np. Europejska Stolica Kultury we Wrocławiu w 2016 r.), naukowym (np. Kongres Międzynarodowej Unii Geograficznej w Krakowie w 2014 r.) i politycznym (np. Konferencja ONZ w Sprawie Zmian Klimatu w Katowicach w 2018 r.) (Borodako i in., 2019; Celuch, 2018; Cieślikowski, 2020; Olipra, 2015).

\section{PODSUMOWANIE}

W ciagu trzech dekad od przemian ustrojowych w Polsce rynek transportu lotniczego znacząco się zmienił. Wzrosła przede wszystkim popularność podróży 
samolotowych po akcesie Polski do Unii Europejskiej i liberalizacji rynku w wyniku zmiany prawa lotniczego. Po 2004 r. dynamicznie zaczęły rozwijać się porty regionalne, co miało dalszy wpływ na zmiany w miastach, w których są zlokalizowane.

Znacząco rozbudowana została infrastruktura lotniskowa i okołolotniskowa. Powstały także nowe porty lotnicze (Lublin) lub zmieniono funkcje kilku lotnisk z wojskowej na cywilną (Modlin i Radom). Wzrost liczby pasażerów wpłynął na decyzje o zmianach w układzie transportu naziemnego - $\mathrm{w}$ wielu przypadkach przebudowano drogi dojazdowe, doprowadzono połączenia kolejowe do portów, zwiększono liczbę połączeń autobusowego transportu publicznego. W pobliżu portów lotniczych można zaobserwować początki tworzenia się węzłów multimodalnych i centrów logistycznych, wpływa to na proces dalszych zmian w zagospodarowaniu przestrzennym. Wokół portów w Warszawie, Gdańsku, Rzeszowie, Wrocławiu rozpoczęto tworzenie stref airport cities, w których wybudowano już pierwsze hotele, centra konferencyjne i kompleksy biurowe.

Rozwój portów regionalnych był istotnym czynnikiem wpływającym na decyzję o lokalizacji inwestycji, powstanie nowych podmiotów gospodarczych oraz wybór miejsca organizacji dużych międzynarodowych wydarzeń. Wzrost dostępności usług transportu lotniczego, rozszerzenie oferty kierunków i częstotliwości połączeń oraz zwiększenie dostępności cenowej wpłynęły na rozwój turystyki przyjazdowej, której rezultaty, o charakterze funkcjonalnym i społecznym, można obserwować głównie w centrach największych miast. Wpłynęły na decyzje o rozbudowie infrastruktury hotelowej, ale również na wzrost popularności innych form zakwaterowania, takich jak hostele i wynajem krótkoterminowy mieszkań.

Pomiędzy rozwojem portów lotniczych a rozwojem miast istnieje efekt synergii. Porty lotnicze przyczyniają się do rozwoju funkcji metropolitalnych miast, a równocześnie rozwój gospodarczy miasta, jego ranga i funkcje wpływają na wielkość ruchu lotniczego.

Rok 2020 okazał się szczególnym czasem zarówno dla światowego, jak i polskiego rynku transportu lotniczego. Wprowadzone ograniczenia w przemieszczaniu się ludności z powodu pandemii, czasowe zamknięcie granic, zawieszanie i niestabilność sieci połączeń spowodowały znaczący spadek liczby pasażerów oraz największy kryzys w historii transportu lotniczego. Kryzys ten będzie miał swoje konsekwencje w najbliższych latach i zapewne spowoduje zmiany w funkcjonowaniu polskich portów lotniczych. Ze szczególnymi problemami finansowymi muszą się liczyć zwłaszcza mniejsze porty regionalne, $\mathrm{w}$ których ruch pasażerski $\mathrm{w}$ ostatnich latach był najmniejszy.

\section{BIBLIOGRAFIA}

ACI (Airport Council International) Europe (2004). The social and economic impact of airports in Europe. York: ACI Europe.

Augustyniak, W. (2017). Analiza progów rentowności polskich regionalnych portów lotniczych. Przegląd Komunikacyjny, 12, 16-19. https://doi.org/10.35117/A_ENG_17_12_03

Awedyk, M., Markiewicz, M., Weltrowska, J. (2013). Indywidualny City Break jako reprezentacyjny trend turystyki europejskiej w XXI w. Prace Naukowe Uniwersytetu Ekonomicznego we Wrocławiu, 304, 11-18.

Bednarczyk, M., Grabińska, E. (2015). Airport competitiveness. Models and assessment methods. Kraków: Jagiellonian University Press. https://doi.org/10.4467/K9380.81/16.16.6979

Bondaryk, P., Gruszczyński, J., Kłosowski, M., Kopański, T.J., Matusiak, W., Puchała, P., Rusiecki, M., Witkowski, R. (2018). Historia lotnictwa w Polsce. Bełchatów: Wydawnictwo Fenix.

Borodako, K., Seweryn, R., Berbeka, J., Niemczyk, A., Davidson, R., Jakóbik, K. (2019). Assessment of meetings industry's economic impact on the city of Krakow. Argumenta Oeconomica, 43 (2), 191-211. https://doi.org/10.15611/aoe.2019.2.08

Button, K.J., Taylor, S. (2000). International air transportation and economic development. Journal of Air Transport Management, 6 (4), 209-222. https://doi.org/10.1016/S0969-6997(00)00015-6

Celuch, K. (2018). Impact of the events sector on the economy - case study of Poland. Economic Problems of Tourism, 44 (4), 69-81. https://doi.org/10.18276/ept.2018.4.44-07

Cieślikowski, K. (2020). Raport. Rynek turystyki biznesowej w Katowicach w 2019 r. Badanie rynkowe uczestników spotkań konferencyjnych. Katowice: Convention Bureau.

Fedyk, W., Sołtysik, M., Olearnik, J., Barwicka, K., Mucha, A. (2020). How overtourism threatens large urban areas: A case study of Wroclaw, Poland. Sustainability, 12, 1783. https://doi. org/10.3390/su12051783

Gierczak-Korzeniowska, B. (2016). Airport City Rzeszów-Jasionka - nowa przestrzeń miejska o globalnym charakterze. W: M. Osińska, I. Urbanyi-Popiołek (red.), Problemy logistyki i zrównoważonego rozwoju (s. 193-206). Bydgoszcz: Wydawnictwo Uczelniane Wyższej Szkoły Gospodarki.

Gierczak-Korzeniowska, B. (2020). Podmiejska Kolej Aglomeracyjna w województwie podkarpackim jako czynnik stymulujący rozwój regionu. Przegląd Komunikacyjny, 2, 97-106.

Google Earth (2020). Pobrane z: https://www.google.pl/intl/pl/ earth/ (15.05.2019).

Graham, A. (2008). Managing airports. An international perspective. Oxford: Elsevier. https://doi.org/10.4324/9780080942667

Halpern, N., Brathen, S. (2011). Impact of airport on regional accessibility and social development. Journal of Transport Geography, 19, 1145-1154. https://doi.org/10.1016/j.jtrangeo.2010.11.006

Hawlena, J. (2012a). Konkurencja na rynku lotniczych przewozów pasażerskich $w$ warunkach globalizacji. Katowice: Uniwersytet Ekonomiczny w Katowicach.

Hawlena, J. (2012b). Rynek niskokosztowych przewozów lotniczych a rozwój sektora turystyki. Radom: Instytut Naukowo-Wydawniczy Spatium.

Hawlena, J. (2016). Znaczenie lotniska Lublin-Świdnik w procesie rozwoju regionu. Autobusy, 12, 1574-1578.

Huderek-Glapska, S. (2010). Port lotniczy w systemie transportu intermodalnego. LogForum - czasopismo internetowe, 6 (5), 47-54.

Huderek-Glapska, S. (2011). Wpływ portu lotniczego na gospodarkę regionu. W: M. Rekowski, Regionalne porty lotnicze w Polsce - charakterystyka i tendencje rozwojowe (s. 193-236). Poznań: Wydawnictwo Uniwersytetu Ekonomicznego w Poznaniu. 
Huderek-Glapska, S. (red.) (2019). Zarządzanie rozwojem portów lotniczych. Warszawa: Wydawnictwo C.H. Beck.

Jankiewicz, J., Huderek-Glapska, S. (2016). The air transport market in Central and Eastern Europe after a decade of liberalisation - Different paths of growth. Journal of Transport Geography, 50, 45-56. https://doi.org/10.1016/j.jtrangeo.2015.06.002

Kołoś, A., Taczanowski, J., Trzepacz, P. (2012). Connecting airports with cities. Perspective for air-links development in Central Europe. Prace Geograficzne, 130, 107-129. https://doi. org/10.4467/20833113PG.12.023.0664

Kowalczyk-Anioł, J. (2019a). Tourismification of the housing resources of historical inner cities. Case of Krakow. Studia Miejskie, 35, 9-25. https://doi.org/10.25167/sm.1014

Kowalczyk-Anioł, J. (2019b). Hipertrofia turystyki miejskiej-geneza i istota zjawiska. Konwersatorium Wiedzy o Mieście, 4 (32), 7-18. https://doi.org/10.18778/2543-9421.04.01

Koziarski, S. (2007). Transport w Polsce. Prace Komisji Geografii Komunikacji PTG, 12, 61-109.

Kubicki, P. (2017). Wpływ studentyfikacji i turystyfikacji na społeczno-kulturową przestrzeń miasta. Miasto. Pamieć i Przyszłość, 2, 63-73. https://doi.org/10.26774/mpp.35

Lijewski, T. (1986). Geografia transportu Polski. Warszawa: Polskie Wydawnictwo Ekonomiczne.

Liwiński, J. (2006). Polskie porty lotnicze w statystyce. Przegląd Komunikacyjny, 6, 8-13.

Marciszewska, E., Kaliński, D. (2009). Port lotniczy jako czynnik rozwoju regionalnego. W: A. Barski, W. Fabirkiewicz, Cz. Jarosz (red.), Rozwój lotnictwa w regionach (s. 11-18). Toruń: Wydawnictwo Adam Marszałek.

Nowak, H., Huderek-Glapska, S. (2019). Rozwój portu lotniczego. W: S. Huderek-Glapska (red.), Zarzadzanie rozwojem portów lotniczych (s. 65-123). Warszawa: Wydawnictwo C.H. Beck.

Olipra, Ł. (2015). Dostępność usług transportu lotniczego jako czynnik lokalizacji inwestycji zagranicznych na Dolnym Śląsku. Prace Naukowe Uniwersytetu Ekonomicznego we Wrocławiu, 380, 368-382. https://doi.org/10.15611/pn.2015.380.34

Olipra, Ł. (2016). Wpływ Portu Lotniczego Wrocław na gospodarkę miasta i regionu - szacowanie i analiza wydatków pasażerów. Studia Oeconomica Posnaniensia, 4 (7), 171-193. https:// doi.org/10.18559/SOEP.2016.7.9

Pancer-Cybulska, E., Olipra, Ł. (2016). Porty lotnicze jako strategiczny czynnik rozwoju regionów w świetle regionalnych dokumentów programowych. Studia Oeconomica Posnaniensia, 4 (7), 127-150. https://doi.org/10.18559/SOEP.2016.7.7

Pancer-Cybulska, E., Olipra, Ł, Cybulski, L., Surówka, A. (2014). Transport lotniczy a regionalne rynki pracy $w$ Polsce. Wrocław: Wydawnictwo Uniwersytetu Ekonomicznego we Wrocławiu.

Pijet-Migoń, E. (2012). Zmiany rynku lotniczych przewozów pasażerskich w Polsce po akcesji do Unii Europejskiej. Wrocław: Uniwersytet Wrocławski.

Pijet-Migoń, E. (2014). Dziesięć lat „otwartego nieba” nad Polską - implikacje dla turystyki. Zeszyty Naukowe Uniwersytetu Szczecińskiego 807, Ekonomiczne Problemy Turystyki, 27, 83-98.

Pijet-Migoń, E. (2016). Etapy rozwoju regionalnych portów lotniczych w Polsce i innych państwach Europy Środkowo-Wschodniej po akcesji do Unii Europejskiej. Studia Oeconomica Posnaniensia, 4 (7), 30-58. https://doi.org/10.18559/SOEP.2016.7.2

Pijet-Migoń, E. (2019). Regionalne porty lotnicze w Europie Środkowo-Wschodniej po liberalizacji rynku transportu lotniczego. Prace Komisji Geografii Komunikacji PTG, 22 (2), 63-73. https://doi.org/10.4467/2543859XPKG.19.011.11151
Pomykała, A., Raczyński, J., Graff, M., Bużałek, T. (2019). Porty lotnicze w Polsce i ich obsługa transportowa. Technika Transportu Szynowego, 26 (4), 16-28.

Rekowski, M. (red.) (2011). Regionalne porty lotnicze w Polsce - charakterystyka i tendencje rozwojowe. Poznań: Wydawnictwo Uniwersytetu Ekonomicznego w Poznaniu.

Rosik, P., Komornicki, T., Goliszek, S., Stępniak, M., Pomianowski, W. (2017). Trends in potential accessibility to airport in Poland (AAI Indicator). Europa XXI, 33, 67-78. https://doi. org/10.7163/Eu21.2017.33.5

Rucińska, D., Ruciński, A. (red.) (2000). Marketing ustug lotniczych. Gdańsk: Wydawnictwo Uniwersytetu Gdańskiego.

Rucińska, D., Ruciński, A. (2017). Współzależności rozwoju portów lotniczych i struktur zagospodarowania przestrzeni z uwzględnieniem stref okołolotniskowych, Prace Komisji Geografii Komunikacji PTG, 20 (2), 57-68. https://doi.org/10.44 67/2543859XPKG.17.011.7393

Rucińska, D., Ruciński, A., Tłoczyński, D. (2012). Transport lotniczy. Ekonomika i organizacja. Gdańsk: Wydawnictwo Uniwersytetu Gdańskiego.

Rydzkowski, W. (2014). Dylematy budowy portu lotniczego Gdynia-Kosakowo - próba oceny decyzji inwestycyjnej. Zeszyty Naukowe Wydziału Ekonomicznego Uniwersytetu Gdańskiego, 50, 5-18.

Sipiński, D., Cybulak, P., Plachta, K. (2016), Lotniska w Polsce. Łódź: Wydawnictwo Księży Młyn.

Sonnenburg, F., Braun, B. (2017). Impact of airports on spatial patterns of metropolitan employment: The case study of Australia. Erdkunde, 71 (4), 287-300. https://doi.org/10.3112/ erdkunde.2017.04.02

Stangel, M. (2013). Rozwój strefy okołolotniskowej a port lotniczy - efekt synergii. Przeglad Komunikacyjny, 7, 18-25.

Stangel, M. (2014). Airport City - strefa okołolotniskowa jako zagadnienie urbanistyczne. Gliwice: Helion.

Szromek, A.R., Kruczek, Z., Walas, B. (2020). The attitude of tourist destination residents towards the effects of overtourism - Kraków case study. Sustainability, 12, 228. https://doi. org/10.3390/su12010228

Tłoczyński, D. (2016). Konkurencja na polskim rynku usług transportu lotniczego. Gdańsk: Wydawnictwo Uniwersytetu Gdańskiego.

Trzepacz, P. (red.) (2014). Polish airports in transition 2004-2013. Kraków: Institute of Urban Development.

Wach-Kloskowska, M. (2020). Development of airport-related zones (the construction of the airport city) as an element of the interdependent development of airports, agglomerations and regions - Gdańsk airport case study. Journal of Regional and City Planning, 31 (2), 199-216. https://doi.org/10.5614/ jpwk.2020.31.2.6

Walas, B. (2019). Turystyczny najem krótkoterminowy w ocenie interesariuszy lokalnych. Biuletyn KPZK, 275, 49-62.

Wróbel, P. (2012). Miasto sieciowe. Airport city i aerotropolis. Architektura, 109 (1), 421-432.

Zmyślony, P., Pilarczyk, M. (2020). Identification of overtourism in Poznań through the analysis of social conflicts. Studia Periegetica, 30 (2), 9-24. https://doi.org/10.5604/01.3001.0014.3169

Artykuł wpłyną: 25 czerwca 2020

Zaakceptowano do druku: 3 grudnia 2020 